EESTI NSV TEADUSTE AKADEEMIA TOIMETISED 1954. III kd., nr. 2

ИЗВЕСТИЯ АКАДЕМИИ НАУК ЭСТОНСКОИ ССР 1954. ТоМ III, № 2

\title{
PÕHJAVEE SÜGAVUSE MÕJU SOOMULLA VILJAKUSELE
}

\section{EISEN}

Juhindudes partei XIX kongressi direktiividest NSV Liidu arendamise viienda viie aasta plaani kohta aastaiks $1951-1955$, tuleb soode ja liigniis. kete maa-alade kuivendamist ning kasutuselevõtmist suurendada $40-45 \%$ võrra.

Soomaadele rajatud kultuuride saagikusele avaldab suurt mõju veerežiim, mistōttu Eesti NSV Teaduste Akadeemia Maaparanduse ja Sookultuuri Instituudis asuti 1950. aastal veerežiimi mõju uurimisele.

Uurimistööde läbiviimiseks rajati katsed Instituudi katsemajandis Toomal madalsoos, mida iseloomustab pilliroo-tarnasturvas väheste metsaning pruunsamblaturba lisanditega. Kohati esines sool enne kultuuristamist hajusalt sphagnum-sambla patju. Soo kõdunemisaste on $20-25 \%$ pirides. Mulla keemilist koostist ja füüsikalisi omadusi iseloomustavad järgmised keskmised arvud: tuhka $5,4 \%$ (kuivaine kaalust), lupja $(\mathrm{CaO}) 2,2 \%$, lämmastikku (N) $2,6 \%$, mulla poorsus $91 \%$, looduslik aeratsioon $7-10 \%$, mahukaal $140 \mathrm{~kg} / \mathrm{m}^{3}$ ja erikaal 1,6 . Turbakihi tüsedus ulatub üle 1,5 meetri. Turbakihi all on pōhimoreen.

Põllu-, heina- ja karjamaataimedele sobiva veerežiimi uurimiseks reguleeriti kirjeldatud madalsoo-alal põhjavee tase enne taimede külvi erinevatesse sügavustesse. Iga erineva kuivendusnormi juures olid agrotehnilised võtted ühtlased. Katsealal, mille suurus on ligikaudu 12 ha, teostati uudiskünd 1949. aasta kevad-suvisel perioodil $35-40 \mathrm{~cm}$ sügavuselt. Künd kuivas ning õhustus kiiresti ja ta tasandati korduvate randaalimistega. Seejärel külvati samal aastal eelviljaks segavili. Järgmisel aastal oli katseväljak veel eelviljade all. Katseväljaku ühele 3 ha suurusele osale, kus turvas oli kõige vähem kõdunenud ning kus esines rohkesti sphagnum-sambla patju, pandi eelviljaks kartul.

Iga-aastaseks jooksvaks väetiseks hakati andma kevadel enne végetatsiooniperioodi algust $60 \mathrm{~kg} \mathrm{P}_{2} \mathrm{O}_{5}$ ja $120 \mathrm{~kg} \mathrm{~K} 2 \mathrm{O}$ hektarile.

Et selgitada tähtsamaid agrobioloogilisi nõudeid soo kultuuristamisel seoses veerežiimi reguleerimisega, on ENSV TA Maaparanduse ja Sookultuuri Instituudis vaatluse all järgmised küsimused: 1) põllu-, heina- ja karjamaataimedele sobivad põhjavee sügavused (kuivendusnormid); 2) erineva sügavusega põhjavee mõju künnikihi füüsíkalistele omadustele; 3) põllumajanduslikele taimedele vajalik veehulk ja künnikihi veedünaamika erinevate põhjavee sügavuste juures; 4) põllumajanduslike kultuuride areng ja soomulla bioloogiline tegevus sõltuvalt põhjavee sügavusest. 
Ohtlasi püütakse elutegurite samaväärsuse seadust aluseks võttes välja selgitada agrobioloogiliste nõuete piirid, mis määravad taimede kasvamiseks kõige soodsama olukorra.

Alljärgnevas on antud lühike ülevaade tulemustest, mis on saadud eelmainitud kuivenduskatselt ja mõnes osas ka tootmispindadelt.

\section{Põllu-, heina- ja karjamaataimedele sobivatest põhjavee sügavustest}

Uldiselt võib öelđa, et põllu-, heina- ja karjamaakultuuride suuremaid ning püsivamaid saake saadi katsealadelt, kus põhjavesi oli rohkem kui $70 \mathrm{~cm}$ sügavusel. Katse maksimaalne kuivendusnorm kolme aasta keskmisena kõikus $95-120 \mathrm{~cm}$ piirides.

Alates kuivendusnormist umbes $80 \mathrm{~cm}$ kuni maksimaalse kuivenduseni suurt saakide juurdekasvu kultuuridel enam ei esinenud. Et enamik kultuure andsid suuremat ning ühtlasemat saaki maksimaalse ja sellele lähedase kuivenduse juures, oli teatud määral üllatus. Seni oldi arvamisel, et sood hakkavad nii intensiivse kuivenduse puhul kannatama liigkuivenduse all. Heina- ja karjamaade kuivendusnormiks soovitatakse tavaliselt ainult $50-60-70 \mathrm{~cm}\left({ }^{6}\right)$.

Põllukultuurid. Vaatluse all olid: talirukis, oder, kanep, kartul, naeris ja suhkrupeet.

Talirukis andis kahe katseaasta jooksul suurima terasaagi, 21,5-24,0 tsentnerit hektarilt, maksimaalse, s. o. $90-120 \mathrm{~cm}$ kuivendusnormi juures. Kuivendusnormi vähenemisega kaasnes pidev saagi langus ja pōhjavee sügavusel $40-50 \mathrm{~cm}$ oli see näiteks ainult $8-10$ tsentnerit hektarilt.

Talirukki sarnaselt reageerisid pōhjavee sügavusele veel kanep ja suhkrupeet.

Odra terasaagis (23 ts hektarilt) ei olnud tunduvat langust märgata enne kui kuivendusnorm langes alla $60 \mathrm{~cm}$. Odra suurim pơhusaak, ligikaudu 80 ts/ha, saadi suurema kuivenduse juures. Kuivenduse nõrgenemisega langes põhusaak pidevalt. Odra eelviljaks oli kartul. Arvatavasti on kartuli kultuuril soodus mõju mulla mikroobide tegevusele ja paljunemisele, mistõttu nende aktiivne toime intensiivistub järgnevaiks aastaiks. Rohke lämmastiku tõttu aga oder lamandus, mis avaldas pidurdavat mõju terasaagile.

Kartuli- ja naerisaak püsis enam-vähem ühtlane kuivendusnormini $60 \mathrm{~cm}$. Edasisel kuivendusnormi vähenemisel langes kartuli- ja naerisaak järsult.

Heintaimede segud. Nii pikemaajaline kui ka lühemaajaline niidusegu andsid pidevalt suurema saagi seal, kus kuivendusnorm oli üle $80 \mathrm{~cm}$. Järsk saagilangus algas heinasegudel siis, kui kuivendusnorm langes alla $70 \mathrm{~cm} .70$ sentimeetrist väiksema põhjavee sügavusega alal oli märgata ka tunduvat umbrohtumist.

1951. aasta põuasel suvel näiteks oli kuivheinasaak kuivendusnormi $100-120 \mathrm{~cm}$ juures 45,5 tsentnerit hektarilt, kuivendusnormi $70-80 \mathrm{~cm}$ juures 36,0 tsentnerit hektarilt ja kuivendusnormi $35-40 \mathrm{~cm}$ juures kõigest 18,4 tsentnerit hektarilt (esimesest niidust).

Graafikutes 1 ja 2 (pikema- ja lühemaajalise niidusegu kohta) kujutatud saagi, mulla aeratsiooni ja veehulga kõverad annavad ülevaate seostest, mis valitsevad nende,ja põhjavee sügavuse vahel. Jälgides näiteks lühemaajalise niidusegu saagi kõverat graafikus 2 , näeme, et põhjavee sügavuseni $70-75 \mathrm{~cm}$ esineb tugev saagi juurdekasv. Põhjavee sügavuse edasisel suurenemisel toimub veel saagi juurdekasv, kuid juba aeglasemas tempos. Ka mulla aeratsiooni ja niiskusetagavara kõverad hakkavad kuivendus- 
normi $75-85 \mathrm{~cm}$ juures liikuma paralleelselt. Nagu hiljem selgub, tähendab see seda, et pōhjavee sügavamale reguleerimisega saab künnikihi niískuserežiimi reguleerida ainult teatud piirideni.

$\mathrm{K}$ a r j a m a a - s e g u. Katsekoplite saakide arvestus toimus 1951. aastal niitemeetodil ja 1952. aastal zootehniliselt (karjatamisega.). Seejuures saadi, alates põhjavee sügavusest $70 \mathrm{~cm}$ kuni maksimaalse kuivenduseni, võrdlemisi ühtlane saak, 1637-1982 söötühikut hektarilt. Põhjavee seisu juures alla $60 \mathrm{~cm}$ saadi karjamaalt toodangut umbes 1000 söötühikut hektarilt. Karjamaatoodang tõuseb järgmistel aastatel koos karjatamise ja sellest tekkiva karjamaa kamara tihenemise arvel.

Lisaks neile saagiandmetele võib tuua veel paar näidet hästikuivendatud

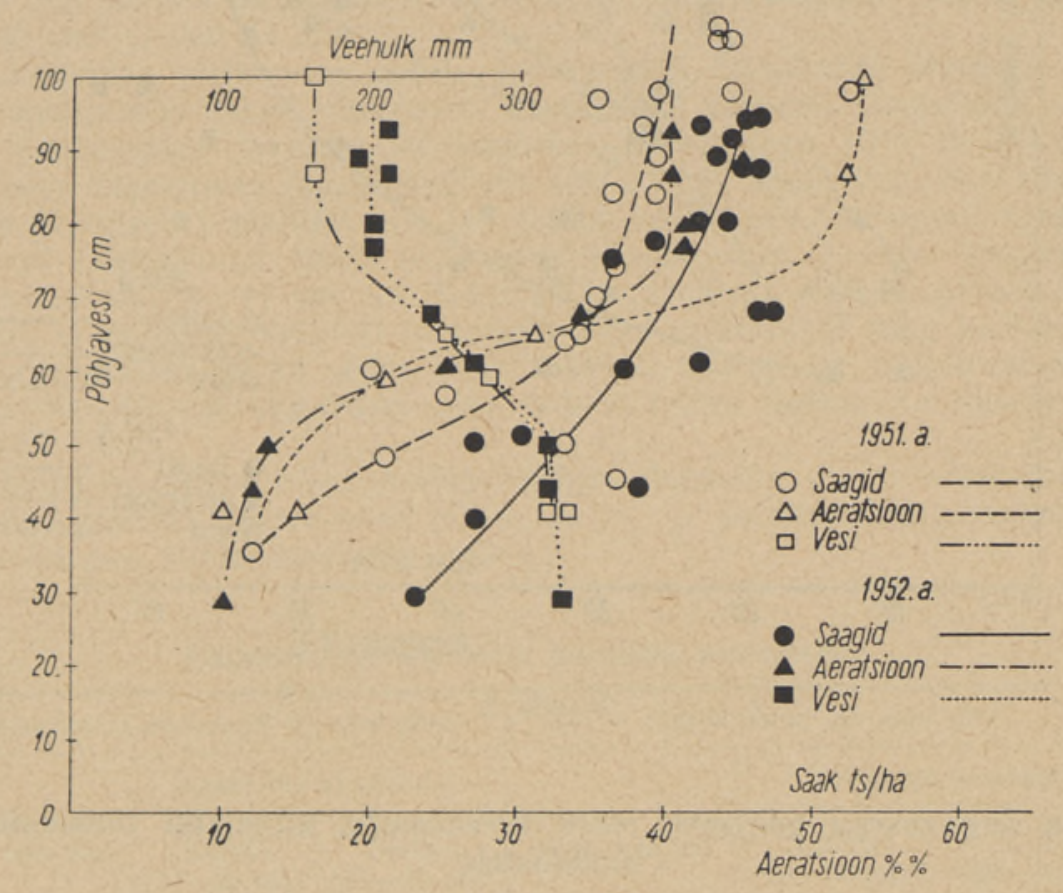

Graafik 1 .

tootmispindadelt, kus turba omadused ligikaudu sarnanevad katsepinna omadega.

ENSV TA Maaparanduse ja Sookultuuri Instituudi ühelt kultuurheinamaalt, kus vegetatsiooniperioodil põhjavee sügavus püsib $1 \mathrm{~m}$ piirides, on saadud nõrgemini kuivendatud pindadega vorrreldes pidevalt kuni $20 \%$ suuremaid saake. Seejuures on ka mulla füüsikalised omadused püsinud rea aastate jooksul taimekasvuks soodsatena.

Sama instituudi nn. ,vana kuivenduskatse” moodustab 8 ha suurune madalsoo-ala, millest 1934. aastal pool kuivendati $70 \mathrm{~cm}$ sügavuselt ja teine pool $120 \mathrm{~cm}$ sügavuselt. 1951. aastal andis viimane 54 ts kuivheina hektarilt, kuna $70 \mathrm{~cm}$ sügavuselt kuivendatud alalt saadi ainult $26 \mathrm{ts} / \mathrm{ha}$ (1. niitmine). Niisama terav oli saakide vahe ka 1952. aastal. Tuleb märkida ka seda, et 70 -sentimeetrise kuivenduse juures on peaaegu kõik dreenid hävinenud, kuna $120 \mathrm{~cm}$ sügavusele pandud dreenid töötavad veel praegu. Dreenide materjaliks olid puufreestorud.

Kokkuvõttes võib märkida, et sügavad vähemkõdunenud madalsood vajavad intensiivset kuivendusvõrku. Kuivendusnorm (põhjavee seis kahe 
veejuhime vahel) ei tohiks peale soo vajumist olla väiksem kui $70 \mathrm{~cm}$ Intensiivse sookultuuri juures tulevad kuivendatud pindadel künnikihi füüsikaliste omaduste ja aeroobsete mikrobioloogiliste protsesside parandamiseks rakendamisele külvikorrad. Külvikordades aga vahelduvad mitmeaastased heintaimed põllukultuuridega, mis ei lepi nõrgema kuivendusega.

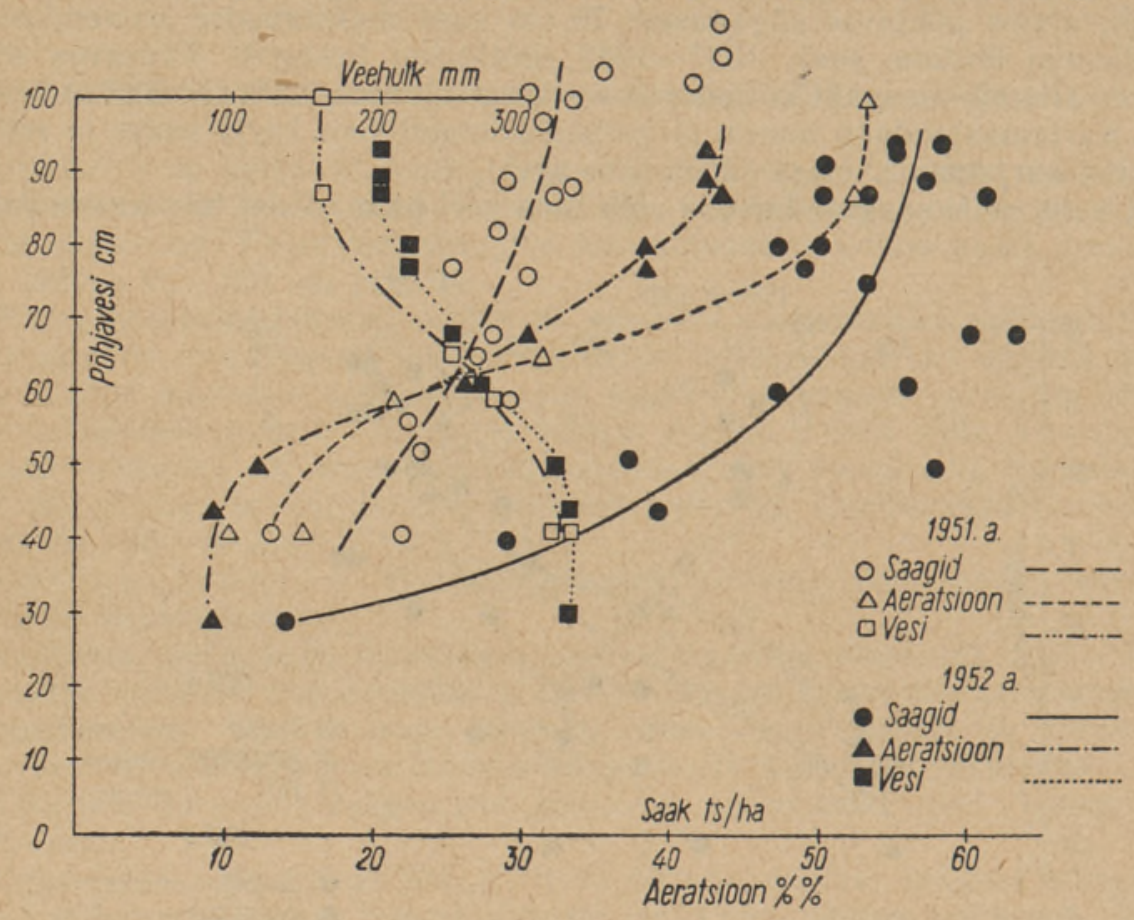

Graafik 2

\section{Erineva sügavusega põhjavee mõju turvasmulla künnikihi fü̈isikalistele omadustele}

Künnikiht on kohaks, kus asub suurem osa kultuurtaime juuri. Juurestiku areng ning tugevus sōltuvad peamiselt künnikihi füüsikalistest omadustest ning selle tüsedusest. Hinnates tugeva juurestiku tähtsust, kirjutas suur nõukogude teadlane akadeemik D. N. Prjanišnikov $\left({ }^{4}\right)$ : „Juurestiku enese arenemine, tema neelava pinna suurenemine kajastub arusaadavalt samuti tema võimel neelata toitaineid." Taime toitumisprotsesside uurimisel on selgunud $\left({ }^{3,4}\right)$, et mineraalainete neelamine sõltub juurte hingamise intensiivsusest. Uhtlasi märgiti, et nii katioonide kui ka anioonide neelamise intensiivsus oleneb juuri ümbritseva keskkonna „ôhustuvusest”, s. t. õhuhapniku sisaldusest. Mida paremini ōhuhapnik pääseb juuri ümbritsevasse keskkonda, seda intensiivsemalt toimuvad rakkudes biokeemilised protsessid, kaasa arvatud ka hingamis-neelamisprotsess. Tähendab, toitumise lahutamatu seos juurte hingamisega juhib jälle tähelepanu elutegurite samaväärsuse seadusele. Taimel on vaja „,süüa”, ,juua” ja ,hingata”; jääb neist kas või ükski tegur ära, pidurdub kohe kogu organismi tegevus $\left({ }^{6}\right)$. Kõrge saagi saamiseks on hädatarvilik, et kõik taimekasvu tegurid oleksid esindatud kindlates harmoonilistes vahekordades, vastavalt taime arengu eri faaside nõuetele. 
Künnikihi füüsikalisi omadusi määrab hulk üksikuid füüsikalisi tegureid, millede vahekordadest oleneb mulla viljakus.

Uurimistulemustest on näha, et tähtsaimateks füüsikalisteks teguriteks on poorsus ja poorides oleva vee ning õhu vahekord ehk aeratsioon.

Poorsuse all mõistetakse ruumala, mille võtavad enda alla õhu ja veega täidetud poorid $100 \mathrm{~cm}^{3}$ mullas. Turvasmulla, samuti turba poorsus jaguneb kapillaarseks ja mittekapillaarseks poorsuseks. Turba mullastamine, s. t. tema vee- ja õhurežiimi korrastamine agrotehniliste võtetega ongi peamiselt kapillaarse ja mittekapillaarse poorsuse vahekorra reguleerimine.

Ohu mahulist hulka turvasmullas nimetatakse aeratsiooniks. Kui näiteks turvasmulla poorsus on $91 \%$ ja aeratsioon $40 \%$, siis tähendab see seda, et $100 \mathrm{~cm}^{3}$ mullas on proovi võtmise ajal pooridevahelist massi $9 \mathrm{~cm}^{3}$, öhku $40 \mathrm{~cm}^{3}$ ja vett $51 \mathrm{~cm}^{3}$.

Taimejuurte piirkonnas uuriti turvasmulla füüsikalisi tegureid ning nende muutumist kahes sügavuses. Uurimiseks kasutati võimalikult muutmata struktuuriga turvasmulla kuubikut mõótmetega $10 \times 10 \times 10 \mathrm{~cm}$. Esimeseks sügavuseks maapinnast oli $10-20 \mathrm{~cm}$, nn. A-kiht. See sügavus haarab peamiselt künnikihi osa, kus leidub hulgaliselt taimejuuri ning kus toimuvad intensiivsed mulla bioloogilised protsessid. Teiseks sügavuseks maapinnast oli $30-40 \mathrm{~cm}$, nn. B-kiht. Tavaliselt on see kiht pärast mulla harimist ja vajumist vahetult künnikihi all. Kuivendatud ning kultuuristunud turvasmullas on ka selles kihis rohkesti taimejuuri. Seepärast arvestatakse $30-40 \mathrm{~cm}$ sügavusel olev B-kiht mulla veevarude käsitlemisel künnikihi hulka.

Füüsikalisi proove võeti analüüsiks igas dekaadis, alates vegetatsiooniperioodi algusest. Proove võeti põllu-, heina- ja karjamaakultuuripindadelt kümne erineva kuivendusnormi juures.

Tabel 1

Põhjavee sügavuse mõju künnikihi aeratsioonile

\begin{tabular}{|c|c|c|c|c|c|}
\hline \multicolumn{3}{|c|}{ Lühemaajalise niidusegu all olev pind } & \multicolumn{3}{|c|}{ Odrakultuuri all olev pind } \\
\hline \multirow{2}{*}{$\begin{array}{l}\text { põhjavee kesk- } \\
\text { mine seis } \mathrm{cm}\end{array}$} & \multicolumn{2}{|c|}{ Keskmine aeratsioon } & \multirow{2}{*}{$\begin{array}{l}\text { Põhjavee kesk- } \\
\text { mine seis } \mathrm{cm}\end{array}$} & \multicolumn{2}{|c|}{ Keskmine aeratsioon } \\
\hline & $\begin{array}{c}\text { A-kihis } \\
(10-20 \mathrm{~cm})\end{array}$ & $\begin{array}{c}\text { B-kihis } \\
(30-40 \mathrm{~cm})\end{array}$ & & $\begin{array}{c}\text { A-kihis } \\
(10-20 \mathrm{~cm})\end{array}$ & $\begin{array}{c}\text { B-kihis } \\
(30-40 \mathrm{~cm})\end{array}$ \\
\hline $\begin{array}{r}123 \\
123 \\
102 \\
99 \\
97 \\
92 \\
82 \\
80 \\
70 \\
60 \\
52 \\
34\end{array}$ & $\begin{array}{l}48,7 \\
46,2 \\
39,0 \\
42,6 \\
40,4 \\
42,7 \\
38,1 \\
35,3 \\
28,7 \\
29,7 \\
15,4 \\
11,3\end{array}$ & $\begin{array}{r}32,7 \\
32,3 \\
32,7 \\
41,4 \\
44,4 \\
43,1 \\
38,7 \\
39,9 \\
30,5 \\
21,9 \\
7,6 \\
7,3\end{array}$ & $\begin{array}{l}84 \\
82 \\
80 \\
76 \\
74 \\
61 \\
53 \\
45 \\
27\end{array}$ & $\begin{array}{l}44,4 \\
44,1 \\
42,0 \\
38,7 \\
36,6 \\
28,3 \\
25,4 \\
19,3 \\
10,2\end{array}$ & $\begin{array}{r}41,0 \\
35,7 \\
35,7 \\
30,2 \\
21,4 \\
11,2 \\
9,6 \\
8,3 \\
9,9\end{array}$ \\
\hline
\end{tabular}

Nagu katsed näitasid, mõjustab põhjavesi künnikihi aeratsiooni, ja nende vahel valitseb seos, kuid ainult teatud põhjaveesügavuseni. Erineva sügavusega põhjavee mõju kultuuristunud turvasmulla aeratsioonile illustreerib tabel 1. Tabelis on võrreldud erinevalt kuivendatud pindade vegetatsiooniperioodi keskmisi põhjavee sügavusi keskmiste aeratsioonidega. Näitena on valitud andmed lühemaajalise niiduseguga pinnalt, millele võrdluseks on toodud samad andmed odrakultuuri põllult. 
Andmeist selgub, et kultuuristunud turvasmullas valitseb seos põhjavee sügavuse ja aeratsiooni vahel ning et see seos muutub vähem märgatavaks vỗi kaob üldse, kui põhjavesi on reguleeritud maapinnast umbes 80 -90 $\mathrm{cm}$ sügavusele. Miks môjustab põhjavesi künnikihis vee ja õhu vahekorda ainult teatud piirini? See oleneb teiste tegurite kõrval suurel määral turvasmulla veemahutavusest. Pealegi saab kuivendusvõrgu abil pinnasest ära juhtida ainult gravitatsioonivett. Sageli esineb juhtum, et drenaaži abil ei saa turba niiskusetagavarasid vähendada taimekasvatusele sobivaks, kuni ei ole loodud mittekapillaarseid poore sisaldavat künnikihti. Eriti esineb selline nähtus vähemkõdunenud soode esimesel kultuuristamisel. Tihedatel turvasmuldadel, kus künnikihi kapillaarne poorsus ei ole veel maaharimisvõtetega tunduvalt kaotatud, ei ole ka märgatavat seost aeratsiooni ja põhjavee sügavuse vahel. Kuivendusnormi suurenemisele vaatamata püsib seal aeratsioon endiselt väike, sest muld on kapillaarveest küllastunud.

Milline seos valitseb põhjavee sügavuse ja künnikihi aeratsiooni vahel kultuurses ning mittekultuurses turvasmullas, näitab tabel 2 . Toodud andmed on vegetatsiooniperioodi keskmised ning pärinevad ühel ja samal ajal kuivendatud enam-vähem sarnastelt madalsootüüpidelt, kus erines ainult pindade agrotehniline ettevalmistus.

Tabel 2

Pōhjavee sügavuse mõju künnikihi aeratsioonile kultuuristunud ja kultuuristumata turvasmullas

\begin{tabular}{|c|c|c|c|c|c|}
\hline \multicolumn{3}{|c|}{ Kultuuristunud turvasmuld } & \multicolumn{3}{|c|}{ Kultuuristumata turvasmuld } \\
\hline \multirow{2}{*}{$\begin{array}{l}\text { Põhjavee } \\
\text { seis cm }\end{array}$} & \multicolumn{2}{|c|}{ Keskmine aeratsioon } & \multirow{2}{*}{$\begin{array}{l}\text { Pōhjavee } \\
\text { seis } \mathrm{cm}\end{array}$} & \multicolumn{2}{|c|}{ Keskmine aeratsioon } \\
\hline & $\begin{array}{c}\text { A-kihis } \\
(10-20 \mathrm{~cm})\end{array}$ & $\begin{array}{c}\text { B-kihis } \\
(30-40)\end{array}$ & & $\begin{array}{c}\text { A-kihis } \\
(10-20 \mathrm{~cm})\end{array}$ & $\begin{array}{c}\text { B-kihis } \\
(30-40 \mathrm{~cm})\end{array}$ \\
\hline $\begin{array}{l}60 \\
52 \\
46 \\
34\end{array}$ & $\begin{array}{l}29,7 \\
15,4 \\
11,5 \\
11,3\end{array}$ & $\begin{array}{r}21,9 \\
7,6 \\
7,1 \\
7,3\end{array}$ & $\begin{array}{l}60 \\
52 \\
47 \\
36\end{array}$ & $\begin{array}{l}12,8 \\
10,8 \\
13,5 \\
10,7\end{array}$ & $\begin{array}{r}10,6 \\
7,5 \\
9,9 \\
9,8\end{array}$ \\
\hline
\end{tabular}

Nagu tabeli andmetest nähtub, ei ole erineva ettevalmistusega mulla aeratsioonis suuri erinevusi väikeste, ligikaudu kuni 50-sentimeetriste kuivendusnormide puhul. Edasi aga ilmnevad mulla füüsikalistes omadustes tunduvad vahed, mis on tingitud künnikihi erinevast ettevalmistusest.

Kui põhjavee tase on reguleeritud kultuurtaimede kasvunõuetele vastavaks ja on loodud mittekapillaarset poorsust omav künnikiht, siis ei võiks ka veemaksimumidel tekkida künnikihi veega täitumist. Künnikihti jääb ainult see osa sademete veest, mida muld suudab siduda. Mulla niiskusesisaldus aga ei ole püsiv. Tavaliselt omandab kultuurne turvasmuld oma maksimaalse veehulga kevadel pärast lume sulamist. Edasi toimub veehulga vähenemine tavaliselt augustikuuni, vaatamata suviseile sademeile. Veevarude vähenemine mullas toimub aurumise teel taimedelt ja maapinnalt, kusjuures aurumise intensiivsus oleneb peale ilmastikuliste tingimuste veel pinnase niiskusest ja taimekasvu intensiivsusest. Uhtlasi on selge, et mida nõrgem on kuivendus, seda rohkem aurub põhjavett. Põhjavee taseme mõõtmised näitasid, et ta vegetatsiooniperioodil langeb, vaatamata kuivendusnormi erinevusele. Seejuures selgus, et mida suurem on kuivendusnorm, seda vähem langeb põhjavee tase, kuid mulla niiskusetagavarad vähenevad rohkem. Kapillaarvee tõusu mõõtmistest järeldus, 
et kuivendusnormi suurenemisega väheneb kultuurses turvasmullas kapillaarvee tõus. Järelikult kasutavad taimed suurema kuivendusnormi juures peamiselt mulla veetagavarasid. On kapillaarvee tõus künnikihini erinevate kuivendusnormide juures muutuv, siis on muutuvad ka künnikihi füüsikalised tegurid. Kuidas on põhjavesi, künnikihi niiskus ja aeratsioon vegetatsiooniperioodil omavahel seotud, seda illustreerivad tabelis 3 toodud arvud.

Esitatud arvudest nähtub seos, mis valitseb vegetatsiooniperioodil põhjavee, künnikihi aeratsiooni ning veetagavara vahel. Näeme, et põhjavesi alaneb kuivendusnormi $100-110 \mathrm{~cm}$ juures suvel vähem kui kuivendusnormi $50-60 \mathrm{~cm}$ juures. Rohkearvulise katsematerjali läbitöötamisel selgus, et mida väiksem on kuivendusnorm, seda suurem on põhjavee alanemine. Oeldut võib veel täiendada järgmiste andmetega tabelist 4 .

Tabel 3

\begin{abstract}
Põhjavee sügavuse mõju künnikihi aeratsioonile ja niiskusevarule mais ja juulis
\end{abstract} 1952. aastal

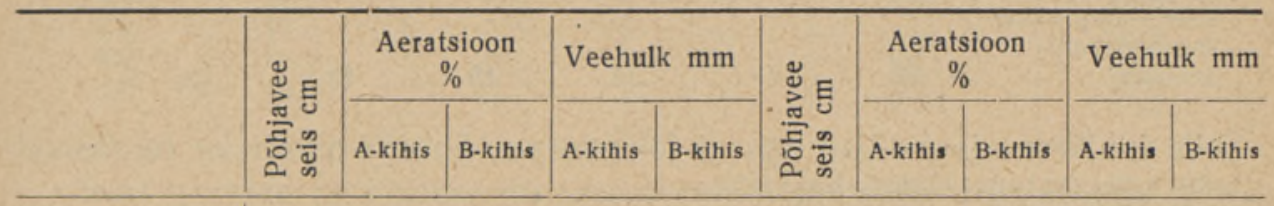

Pikemaajalise niidusegu all oleva mulla fü ü sikalised tegurid

\begin{tabular}{|c|c|c|c|c|c|c|c|c|c|c|}
\hline vis & $\begin{array}{r}99 \\
109 \\
+11\end{array}$ & $\begin{array}{r}21,0 \\
+21,3 \\
\text { L ü h e }\end{array}$ & $\begin{array}{r}47,2 \\
+16,0\end{array}$ & $\begin{array}{r}62,9 \\
40,2 \\
-22.7\end{array}$ & $\begin{array}{r}60,8 \\
46,7 \\
-14,1\end{array}$ & $\begin{array}{r}68 \\
+15\end{array}$ & $\begin{array}{r}32,5 \\
+14,2\end{array}$ & $\begin{array}{r}8,7 \\
11,9 \\
+3,3\end{array}$ & $\begin{array}{r}58,3 \\
-13,4\end{array}$ & 81 \\
\hline gurite erinevus & $\begin{array}{l}10 \\
11\end{array}$ & $\begin{array}{l}33,6 \\
52,7\end{array}$ & $\begin{array}{r}70,7 \\
+4,3\end{array}$ & $\begin{array}{r}-18,1 \\
-18\end{array}$ & $\begin{array}{r}50,3 \\
-4,0\end{array}$ & $\begin{array}{r}-46 \\
59 \\
+13\end{array}$ & $\begin{array}{r}21,7 \\
+11,8\end{array}$ & $\begin{array}{r}12,1 \\
17,0 \\
+4,9\end{array}$ & $\begin{array}{r}74 \\
63 \\
-11\end{array}$ & \\
\hline
\end{tabular}

Jälgides 9 aasta keskmisi põhjavee kõikumise amplituude tabelis 4 , näeme, et mida laiem on dreenide vahe, seda suurem on põhjavee kõikumise amplituud. Huvitav on märkida erinevusi põhjavee sügavuses, mis valitsevad $120 \mathrm{~cm}$ ja $70 \mathrm{~cm}$ sügavuste kuivenduste juures. Kui 120 -sentimeetrise kuivendussügavuse juures valitseb seaduspärasus: mida väiksem dreenide vahelaius, seda sügavam põhjavee seis, siis 70 -sentimeetrise kuivendussügavuse juures on see vastupidine: mida laiem dreenide vahe, seda sügavam suvine põhjavee seis. Hiljem selgub, ét see on suurel määral põhjustatud kapillaarvee tõusust pinnale ning sellest tingitud suuremast auramisintensiivsusest. Tabelist 4 selgub ka, et hoogsa taimekasvu ajal, juulis, mil põhjavesi on saavutanud suurima sügavuse, on olnud suurim ka sademete hulk. Esitatud näited põhjavee kõikumise kohta ei ole maksvad allikalise ja survelise toitumisega soodele, kus pōhjavee taseme kõikumine on tunduvalt väiksem ning kuivenduskraavid töötavad kogu vegetatsiooniperioodil. Eelöeldust võiks järeldada, nagu ei oleks põhjavee toitumisega madalsoode kuivendamiseks intensiivset kuivendusvõrku tarviski, sest pōhjavesi alaneb suvel isegi küllaldasele sügavusele. Nii see aga ei ole.

Pinnalt aurumise teel võib pōhjavesi suve jooksul ainult lühikeseks ajaks langeda kultuurtaimede kasvuks enam-vähem sobivale sügavusele. 
9 aasta* keskmised põhjavee sügavused sentimeetrites ja sademed millimeetrites taimekasvu ajal kuude järgi

\begin{tabular}{|c|c|c|c|c|c|c|c|}
\hline \multirow[b]{2}{*}{$\mathrm{K} \mathrm{u} \mathrm{u}$} & \multicolumn{3}{|c|}{ Dreenide sügavus $70 \mathrm{~cm}$} & \multicolumn{3}{|c|}{ Dreenide sügavus $120 \mathrm{~cm}$} & \multirow{2}{*}{ 总 } \\
\hline & $\begin{array}{c}\text { vahelaius } \\
50 \mathrm{~m}\end{array}$ & $\begin{array}{c}\text { vahelaius } \\
35 \mathrm{~m}\end{array}$ & $\begin{array}{c}\text { vahelaius } \\
20 \mathrm{~m}\end{array}$ & $\begin{array}{c}\text { vahelaius } \\
50 \mathrm{~m}\end{array}$ & $\begin{array}{c}\text { vahelaius } \\
35 \mathrm{~m}\end{array}$ & $\begin{array}{c}\text { vahelaius } \\
20 \mathrm{~m}\end{array}$ & \\
\hline $\begin{array}{l}\text { Mai } \\
\text { Juuni } \\
\text { Juuli } \\
\text { August } \\
\text { September } \\
9 \text { aasta keskmine }\end{array}$ & $\begin{array}{l}60 \\
73 \\
78 \\
76 \\
71 \\
72\end{array}$ & $\begin{array}{l}58 \\
70 \\
75 \\
73 \\
71 \\
69\end{array}$ & $\begin{array}{l}56 \\
67 \\
72 \\
70 \\
67 \\
67\end{array}$ & $\begin{array}{l}65 \\
78 \\
84 \\
83 \\
80 \\
78\end{array}$ & $\begin{array}{l}70 \\
83 \\
88 \\
88 \\
85 \\
83\end{array}$ & $\begin{array}{l}82 \\
90 \\
95 \\
94 \\
91 \\
90\end{array}$ & $\begin{array}{r}45,8 \\
56,1 \\
105,9 \\
75,3 \\
65,8 \\
348,9\end{array}$ \\
\hline $\begin{array}{l}9 \text { aasta keskmine } \\
\text { põhjavee kõiku- } \\
\text { mise amplituud } \\
\text { vegetatsiooni- } \\
\text { perioodil }\end{array}$ & 18 & 17 & 16 & 19 & 18 & 13 & \\
\hline
\end{tabular}

Selle lühikese aja jooksul aga ei jõua turvas hakata muutuma turvasmullaks ega kultuurtaimed kasvada.

Tabelist 3 on näha veel seda, et aeratsiooni suurenemine suvel erinevate kuivendusnormide juures ei ole võrdeline põhjavee alanemisega.

Miks alaneb väiksema kuivendusnormi juures põhjavee pind rohkem ja mulla niiskus vähem? Seda põhjustab kapillaarvee tõus, mille mõjul künnikiht hoitakse nõrgema kuivenduse juures märjem ning aurumine sealt on seetōttu suurem.

Popovi süsteęmi aurumismõõtjate abil on selgitatud, et ühtlastes pinnaseoludes kuivendusnormi vähenemisega tõepoolest suureneb tunduvalt kapillaarvee tõus ning aurumine. Tabelis 5 toodud andmed kapillaarvee tõusu kohta on saadud 1952. aastal.

Tabel 5

Kuivendusnormi mõju kapillaarvee tõusule

\begin{tabular}{c|c|c|c}
\hline \multicolumn{4}{c}{ Vegetatsiooniperioodi keskmine } \\
\hline $\begin{array}{c}\text { Põhjavee } \\
\text { seis cm }\end{array}$ & $\begin{array}{c}\text { Kapillaarvee } \\
\text { tôus künnikihis } \\
25 \mathrm{~cm} \text { sügavusel } \\
\text { mm }\end{array}$ & $\begin{array}{c}\text { Aeratsioon } \% \\
\text { A-kihis } \\
(10-20 \mathrm{~cm})\end{array}$ & $\begin{array}{c}\text { Niiskus mm } \\
\text { A-kihis } \\
(10-20 \mathrm{~cm})\end{array}$ \\
\hline & & & \\
99 & 26,6 & 42,6 & 48,5 \\
39 & 35,8 & 35,3 & 55,7 \\
32 & 223,3 & 9,7 & 84,0
\end{tabular}

Tabelist selgub ühtlasi kapillaarvee mõju künnikihi aeratsioonile ja niiskusevarule. Seal, kus künnikihti ei ole vổi kus künnikihi kapillaarsus on vajumise teel uuesti taastunud, tõuseb kapillaarvesi kuni pinnani.

Kui on teada künnikihi veerežiimi reguleerimise võimalused, siis on vajalik teada ka niiskuse hulka või tagavara künnikihis, mis kindlustab mulla küllaldase õhustuvuse ning püsivad taimesaagid. Missugune on kōige

* Tabelis 4 toodud andmed põhjavee taseme kohta on kogutud kuivenduskatselt aastatel 1934-1944. Aastate 1937 ja 1938 andmed on sōja ajal kaduma läinud. 
soodsam niiskus künnikihis, see selgub taimekasvu jälgimisel ühtlastes mullastikutingimustes, kuid erinevate niiskuseastmete juures.

Kuidas avaldab künnikihi erinev niiskus mõju saagile ning milline on seejuures põhjavee osatähtsus, see selgub tabelist 6 .

Tabel 6

Künnikihi mulla veesisaldus (protsentides täielikust niiskusemahutavusest) ning selle mōju heinasaagile

\begin{tabular}{c|c|c|c|c|c}
\hline \multicolumn{3}{c}{ 1951. a. keskmine * } & \multicolumn{3}{c}{ 1952. a. keskmine } \\
\cline { 5 - 6 } $\begin{array}{c}\text { Põhjavee } \\
\text { seis cm }\end{array}$ & $\begin{array}{c}\text { Künnikihi } \\
\text { veesisal- } \\
\text { dus ** }\end{array}$ & $\begin{array}{c}\text { Kuivheina } \\
\text { saak ts/ha }\end{array}$ & $\begin{array}{c}\text { Põhjavee } \\
\text { seis cm }\end{array}$ & $\begin{array}{c}\text { Künnikihi } \\
\text { veesisaldus ** }\end{array}$ & $\begin{array}{c}\text { Kuivheina } \\
\text { saak ts, ha }\end{array}$ \\
\hline & & & & & \\
105 & 44,8 & 37,7 & 95 & 55,9 & 42,0 \\
97 & 43,2 & 31,6 & 90 & 56,1 & 45,6 \\
84 & 43,6 & 34,1 & 87 & 55,1 & 41,8 \\
65 & 66,4 & 30,0 & 77 & 55,2 & 38,9 \\
50 & 77,0 & 27,2 & 61 & 73,2 & 42,3 \\
60 & 87,2 & 22,6 & 44 & 85,4 & 27,5 \\
35 & 89,4 & 11,3 & 28 & 89,5 & 22,8 \\
\end{tabular}

Seos saakide ja ülemise 40 -sentimeetrise mullakihi veesisalduse vaheI on kujutatud graafikuil 3 ja 4 .

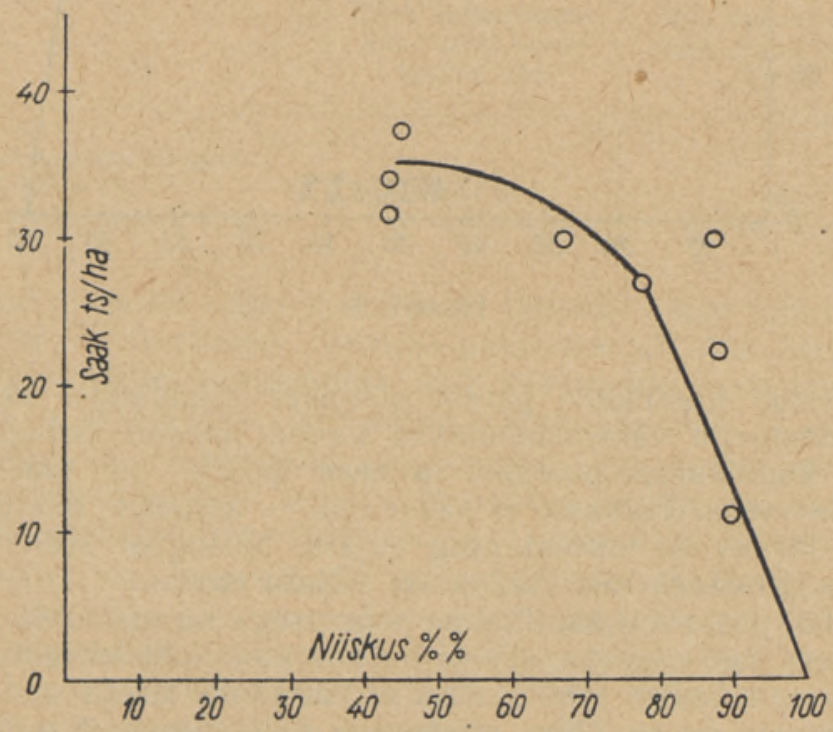

Graafik 3.

Katsematerjali analüüsist selgus, et künnikihi optimaalseks keskmiseks niiskuseks on kultuurtaimede puhul $50-65 \%$ mulla täielikust veemahutavusest. Kõrvalekalded sellest seaduspärasusest võivad olla tingitud mulla kemismist.

Avaldades õhu ja vee hulga protsentides turvasmulla mahust, võib

* 1951. aastal toimus niidukülv.

** Veesisalduse \% 40-sentimeetrise kihi kohta on arvutatud $10-20 \mathrm{~cm}$ sügavuse (A) ja $30-40 \mathrm{~cm}$ sügavuse (B) kihi keskmiste füüsikaliste tegurite järgi. 
lugeda optimaalseteks piirideks künnikihi aeratsioonile $35-50 \%$ ja veehulgale $45-60 \%$.

Eespool selgus, et kuivendustöödega ei ole võimalik iga turvasmulla puhul saavutada taimekasvuks optimaalset vee- ja õhurežiimi. Madalsoode turbad võib kapillaarse ja mittekapillaarse poorsuse vahekordade alusel jagada kahte rühma. Esimese rühma moodustavad hästikõdunenud ja juba kord kultuuristunud turvasmullad. Neil muldadel esineb kapillaarse poorsuse kõrval tavaliselt ka mittekapillaarset poorsust ning nende vee- ja õhu-

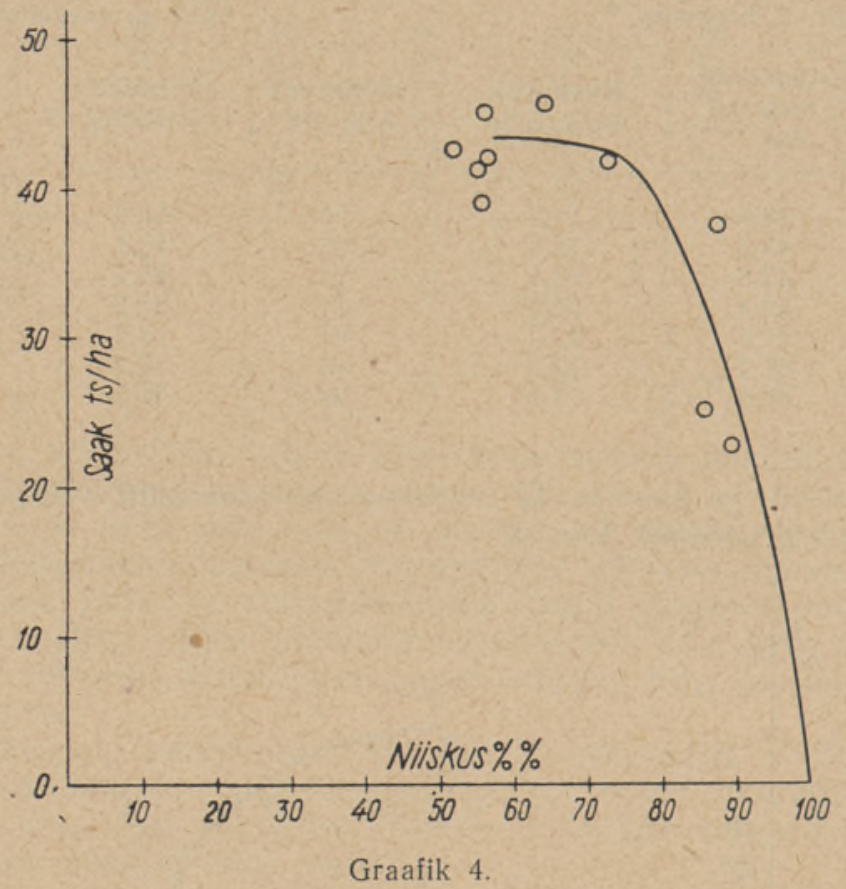

režiim korrastub künnikihis pärast põhjavee alandamist kergesti. Teise rühma moodustavad vähemkōdunenud toored tihedad turbad. See turvas omab suurt kapillaarset poorsust ja need poorid on pidevalt täidetud hapnikuvaese veega. Turbasse ei pääse õhk - aeroobne mikrofloora ei saa elustuda ja turvas on surnud ning viljatu. Niisugust surnud orgaanilist massi ei saa nimetada mullaks, ta on viljatu turvas.

Kui tihedat, peamiselt kapillaarse poorsusega turvasmulda peale kuivendamist esimest korda künda, siis ei purune künnikiht küllaldaselt. Ta pööratakse tavaliselt ümber $\left(180^{\circ}\right)$, ilma et künnikihti tekiks mainimisväärselt mittekapillaarseid poore. Olles niiskusega küllastunud (kapillaarvee tõttu, mida drenaaž ei kõrvalda), vajub 35-40 $\mathrm{cm}$ paksune ümberpööratud raske künniviil tihedalt vastu vaopōhja ning künnikihi kapillaarsus taastub kiiresti. Mõnedes kohtades saab küll künnikihti aluskihist värvuse järgi eraldada, kuid lähemal vaatlemisel selgub, et nende kihtide tiheduste vahel ei ole mainimisväärset erinevust. Kapillaarvesi toidab edasi künnikihti, takistades mulla aereerumist ja seega ka mulla viljakuse kasvamist.

Pärast kündmist lõhutakse kündi randaali abil ainult heal juhul $10-20 \mathrm{~cm}$ sügavuselt. Siin tekib juba mittekapillaarseid poore, turbasse pääseb õhku ning hakkab muutuma turba veerežiim, kuid see õhuke kiht, alludes meteoroloogilistele tingimustele, ei suuda rahuldada taimekasvu ega mikrobioloogiliste protsesside nõudeid. Turvas hakkab küll mullastuma, 
kuid õhukese kultuurkihi tõttu ületavad taimesaagid vaevalt pealtparandusvōtetega saadava saagi.

Tiheda turba mullastamisel tuleb peamine rõhk panna kogu künnikihi kapillaarse poorsuse vähendamisele, künnikihi põhjalikule läbituulutamisele (aereerimisele) ja bioloogiliselt aktiivseks muutmisele. Seda saavutatakse eelviljade kasvatamise ja nende koristamisele järgneva kündmise teel. Eelvilja ja sellele järgneva künni mõju näitavad ENSV TA Maaparanduse ja Sookultuuri Instituudi sellekohase katse andmed. Katse uudissookünd teostati pärast kuivendamist 1950. aastal. Pärast eelvilja, enne heinaseemne külvi 1952. aasta kevadel, künti pool kopli pinda (umbes 1,5 ha) $25-30 \mathrm{~cm}$ sügavuselt, kuna pool koplit jäi võrdluseks ümber kündmata.

Eelviljajärgseks künniks kasutati viiesahalist põllukünniatra. Pinnases leiduvatele kändudele ja juurtele vaatamata saadi kündi teostada ilma suuremate raskusteta. Teistkordsel künnil ei teostatud mulla viilu täielikku ümberpööramist. Künni tulemused olid mainimisväärsed, olgugi et ümberkünd oleks tulnud teostada võimalikult kohe pärast eelvilja koristamist 1951. aasta augustis. Sellega oleks saanud eelvilja all mullastuma hakanud turvast hoida kauem künnivagudes, kus ta oleks suurema aurumispinna tõttu paremini kuivanud ning aereerunud. Dreenide vahelaius oli kuivendamisel $45 \mathrm{~m}$.

Saagi koristamisel ning künnikihi füüsikaliste omaduste analüüsimisel saadi järgmised tulemused:

\begin{tabular}{l|c|c}
\hline & $\begin{array}{c}\text { Enne heinaseemne } \\
\text { külvi teist korda } \\
\text { küntud alal }\end{array}$ & $\begin{array}{c}\text { Alal, kus oli teos- } \\
\text { tatud ainult uudis- } \\
\text { künd }\end{array}$ \\
\hline $\begin{array}{c}\text { Keskmine aeratsioon } 40 \cdot \text { senti- } \\
\text { meetrises kihis }(\%,)\end{array}$ & 17,8 & 7,6 \\
Külviaasta toorheinasak- ts ha & 110 & 56
\end{tabular}

Juba esitatud arvudest nähtub, kui suurt tähtsust omab agrotehnika vee ja õhu vahekorra reguleerimisel tihedates uudissoomuldades. Seejuures aga ei ole käesolevas näites agrotehnika abil saavutatud veel taimekasvuks optimaalset mulla aeratsiooni, mis peaks olema $35-50 \%$.

Järelikult tuleb uutel tihedatel soopinnastel, kus turbal on peamiselt kapillaarne poorsus, künnikihi vee- ja õhurežiim reguleerida taimekasvule sobivaks nimelt agrotehniliste võtete abil, s. t. luua aktiivne künnikiht.

Allpool käsitletakse katseväljaku künnikihi veerežiimi. Kuivendusvõrguga juhime turbast ära üleliigse vaba vee ja sellega langeb pōhjavee pind projekteeritud sügavusele. Peamiselt kapillaarset poorsust omava turba niiskus väheneb põhjavee alandamisega võrdlemisi vähe. Teatavasti väheneb turvasmulla niiskus pōhjavee alanemise tagajärjel seda rohkem, mida rohkem temas esineb mittekapillaarset poorsust. Mittekapillaarsetes poorides alaneb vesi oma raskuse mõjul ja vabastab poori õhule, mistõttu mulla niiskus väheneb. 1951. ja 1952. aastal teostatud mullaniiskuse mõõtmised näitasid, et tihe drenaaž suudab mittekapillaarset poorsust omava iurvasmulla niiskust vähendada künnikihis keskmiselt 87\%-ni (toorturba kohta). Sellest veesisaldusest allapoole drenaaž turvasmulda enam ei kuivenda. Künnikihi niiskuse vähenemisel keskmiselt $87 \%$-le kaaluliselt loo*turba kohta jäi $40 \mathrm{~cm}$ paksusse mullakihti veel keskmiselt $280 \mathrm{~mm}$ velt, kuna mulla aeratsioon püsis $20 \%$ piirideś. Sügavama kuivendusega aladel (kuivendusnorm $80 \mathrm{~cm}$ ja rohkem), kus on loodud hea mittekapillaarset poo:sust omav künnikiht, jääb mulda veel vähem vett. Nii oli $20 .-25$. aprillil 
1952. aastal sellise künnikihi aeratsioon juba $30-35 \%$ ja $40 \mathrm{~cm}$ paksuses kihis vett $240 \mathrm{~mm}$. Niisugune aeratsioon ja veehulk saab kultuurses künnikihis olla sellise kuivenduse juures, kus põhjavee ja künnikihi füüsikaliste omaduste vahel ei ole enam märgatavat seost.

Edasi on katsetega kindlaks tehtud, kui suure hulga vett võtab taim kultuursest turvasmullast närtsimise momendini. Taimedele kättesaamatut veetagavara mullas nimetatakse surnud veetagavaraks. Katsed näitasid, et kultuursel turvasmullal algab heintaimede närtsimine 50-55-kaaluprotsendilise niiskuse juures. Seda niiskust millimeetritesse ümber arvutades näeme, et $10 \mathrm{~cm}$ paksuses turvasmullakihis oleks nn. surnud veetagavara ligikaudu $15 \mathrm{~mm}$ ja $40 \mathrm{~cm}$ paksuse mullakihi surnud veetagavara seega umbes $60 \mathrm{~mm}$. Kasuliku niiskuse tagavara $40 \mathrm{~cm}$ paksuses turvasmullakihis on niisiis keskmiselt $180 \mathrm{~mm}$ (s. o. $240-60$ ). Olgu tähendatud, et 180-millimeetrine niiskusevaru leidub võrdlemisi hea veemahutavusega mineraalmaa $1 \mathrm{~m}$ paksuses kihis.

Eesti NSV-s esineb suurim sademetehulk just vegetatsiooniperioodil, mil seetõttu mulla veetagavarad pidevalt täienevad. 1951. aasta vegetatsiooniperioodil oli sademeid $250 \mathrm{~mm}, 1952$. aastal aga koguni $553 \mathrm{~mm}$. 5 aasta (1948-1952) keskmine vegetatsiooniaegne sademetehulk on ENSV TA Maaparanduse ja Sookultuuri Instituudi andmeil $328 \mathrm{~mm}$. Aurumine kultuuristunud soopinnalt (koos heinakultuuriga) oli 1952. aastal $384-477 \mathrm{~mm}$, olenedes kuivendusnormist. (Kuivadel aastatel on aurumine $15-20 \%$ väiksem.)

Taimekasvuks on seega vegetatsiooniperioodil kultuurse turvasmulla veetagavarad umbes 100 -sentimeetrise kuivendusnormi juures järgmised: kasulik niiskusetagavara 40 -sentimeetrises kihis $180 \mathrm{~mm}$; keskmine sademetehulk vegetatsiooniperioodil $328 \mathrm{~mm}$; kasulikku niiskust kokku $508 \mathrm{~mm}$.

Kultuurtaimede keskmine veevajadus vegetatsiooniperioodil ja pinna auramine $400-440 \mathrm{~mm}$; kasuliku veetagavara ülejääk $108-68 \mathrm{~mm}$.

Tavaliselt toimub meie oludes kõige intensiivsem taimekasv ning peamine heinasaagi kujunemine mai- ja juunikuu jooksul. Uldiselt on need kuud sademetevaesed. 5 aasta keskmisena on mai- ja juunikuu jooksul esinenud sademeid $121,5 \mathrm{~mm}$. Kui turvasmulla kasulikule niiskusele liita mai-juuni sademed, siis näeme, et ka vegetatsiooniperioodi algul ei esine isegi intensiivse kuivenduse puhul taimedel niiskusepuudust. Nii selgub, et kirjeldatud tüüpi madalsoodel ei esine liigkuivendust ega taimedel niiskusepuudust, sest künnikihi veebilansist on pealegi välja jäetud veehulk, mis tungib suvistel põuaaegadel künnikihti kapillaarveena.

Ilmastiku teguritest, mis mõjutavad taimekasvu vegetatsiooniajal, on kahtlemata suur tähtsus sademetel.

Mulla viljakuse seisukohalt on efektiivne ainult see sademete hulk, mis mulda jääb, kuna äraauruvad ja äravoolavad sademed lähevad mullale kaduma. Kasulikku, muldajäävat niiskust võib väljendada järgmiselt: $\mathrm{K}=\mathrm{S}-(\mathrm{A}+\ddot{\mathrm{A}})$, milles $\mathrm{K}$ on kasulik niiskus, $\mathrm{S}$ - sademete hulk $(\mathrm{mm})$, A - aurumine $(\mathrm{mm})$ ja $\AA$ - äravool $(\mathrm{mm})$. Valemis toodud $K$ võib loomulikult osutuda mõne ajavahemiku kohta ka negatiivseks (sademeteta suvepäevad). Seda niiskuse hulka on otstarbekam võtta mitte ühe päeva kohta, vaid pikema ajavahemiku, näiteks iga dekaadi kohta alates vegetatsiooniperioodi algusest. 1952. aastal on võetud alguseks 25. aprill.

Kui vegetatsiooniperioodi algul mullas leiduvale kasuliku niiskuse varule lisada järjest dekaadide viisi saadud niiskus $K$, siis selgub kasulik niiskusevaru iga dekaadi lõpuks (tabelid 7 ja 8 ) Graafikus kujutatult annab 


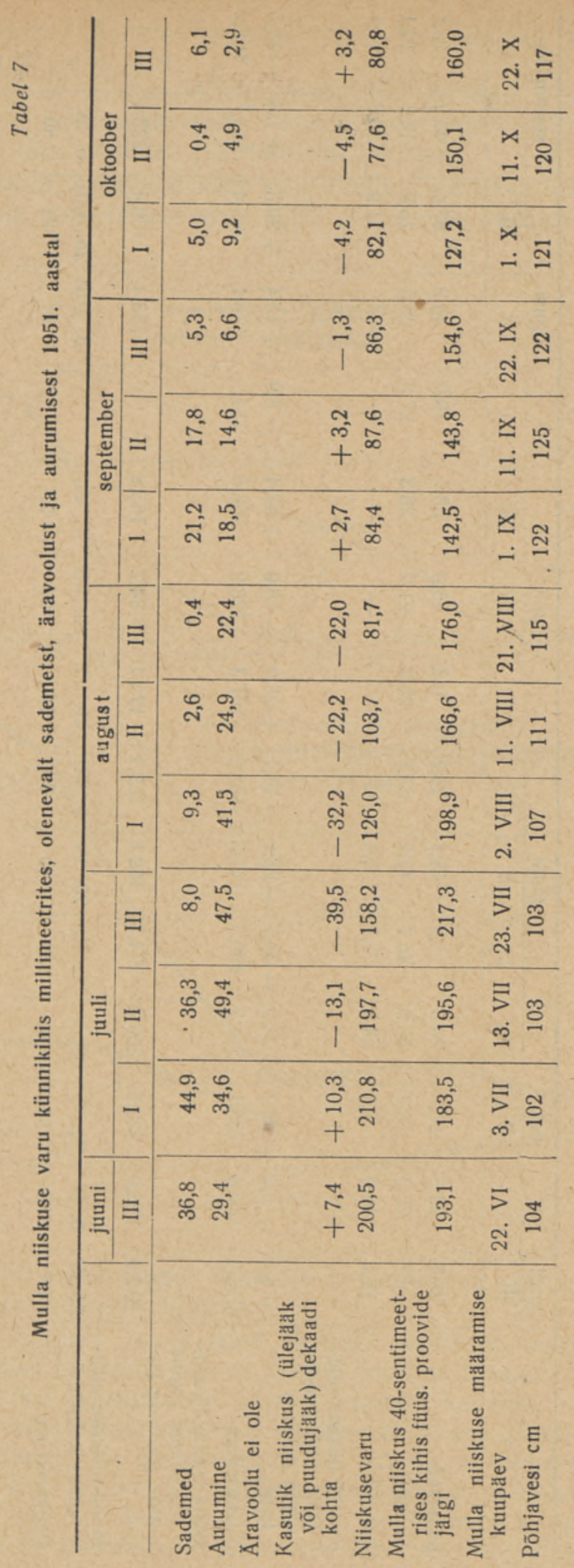




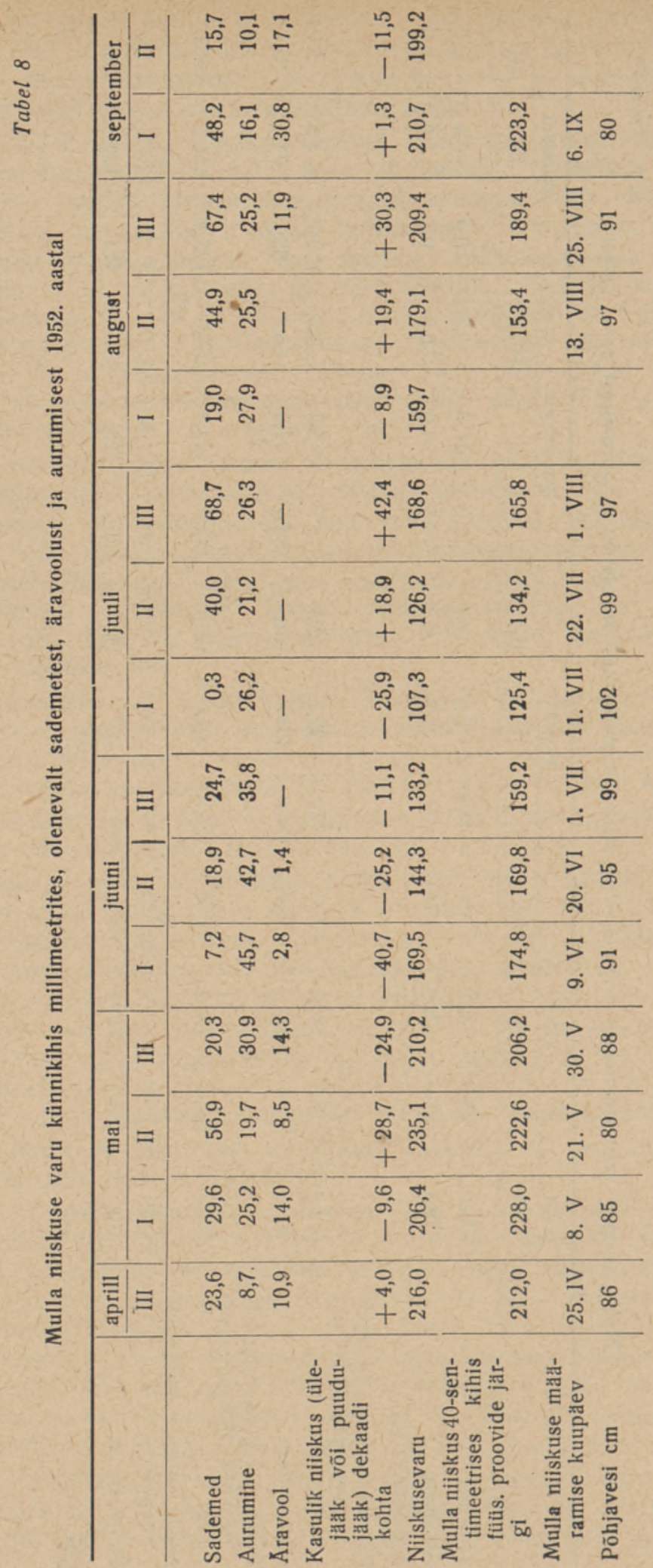


see niiskusevaru tüüpilise kõvera, mis iseloomustab mullas leiduvat niiskust (graafikud 5 ja 6).

Graafikutes on võrdluseks kujutatud 1951. ja 1952. aasta kui väga erinevate aastate niiskusekõverad. Kõvera iga langus näitab niiskuse kao perioodi, iga tõus niiskuse juurdetuleku perioodi.

1951. aasta oli sademetevaene ning mulla niiskusevarud ei tõusnud kuni oktoobri lõpuni normaaltasemeni. 1952. aasta mais olid ülekaalus sademed,

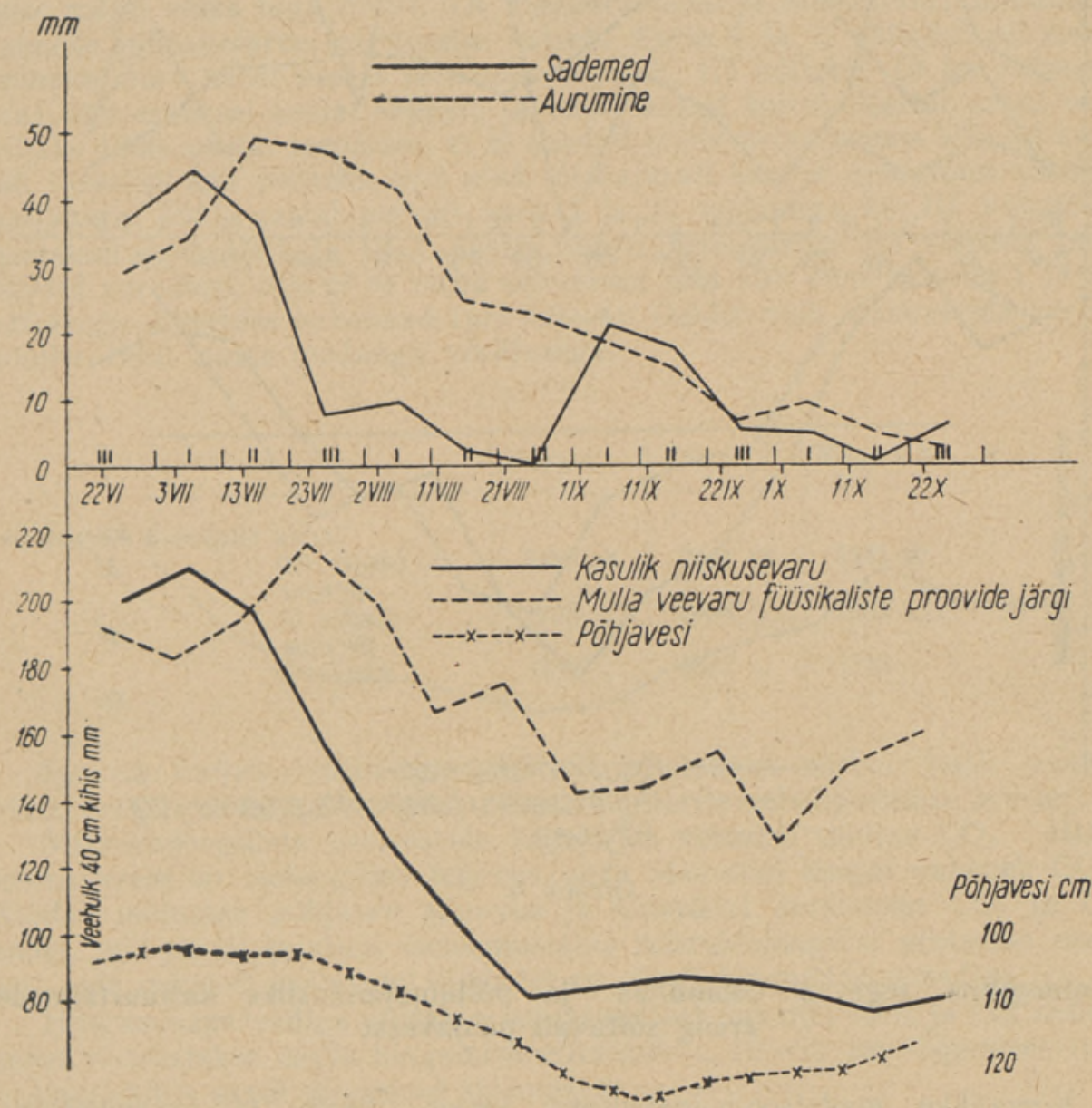

Graafik 5 .

juunis ja juulis esines tugev niiskuse kadu mullast, juulis aga hakkasid mulla niiskusevarud jälle tõusma.

Aurumise andmed on saadud Popovi süsteemi aurumismõõtjatega 100 -sentimeetrise kuivendusnormi juures. Samast kohast on pärit ka äravoolu hulgad. Kui graafikutest 5 ja 6 vaadata kasuliku niiskuse kõverat ning seda võrrelda mulla niiskuse faktilise kõveraga (faktiline niiskus on määratud mullaniiskuse proovidega), siis nähtub, et nad jälgivad üksteist, kuid ei ühtu. Eriti juuni- ja juulikuus on kasuliku niiskuse kõvera järgi mullas vähem vett, kui seda on faktiliselt. Nende kahe kõvera vahe näitab, kas künnikihis on ülekaalus kapillaarvee tõus või infiltratsioon. 


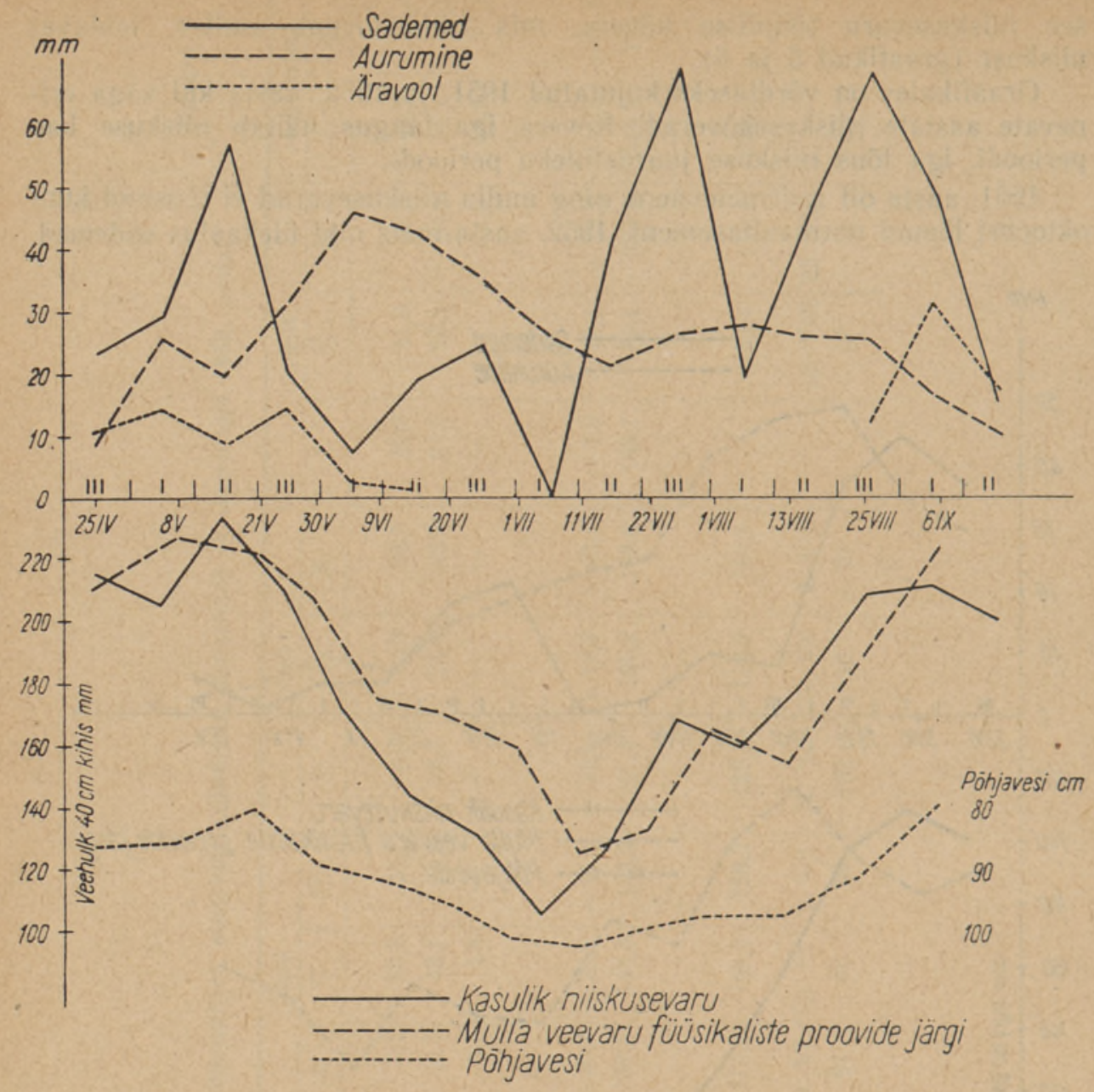

Graafik 6. Bioloogiline tegevus soomullas ja põllumajanduslike kultuurtaimede
areng sõltuvalt põhjaveest

Korralikku madalsoo-heinakultuuri fosfor-, kaali- ja vaseväetisega reeglikohaselt väetades saame igal aastal hektarilt heinasaagi, mis sisaldab $70-100 \mathrm{~kg}$ puhast lämmastikku. See lämmastik on pärit turvasmullast, kus ta vabanes mikrobioloogiliste protsesside tagajärjel.

Kui meie eesmärgiks on saada turvasmuldadelt suuri püsivaid saake ainult fosfor-kaaliväetise foonil, siis tuleb luua eeldused, mis kindlustavad turvasmulla kõdunemise. Aeroobsed mikroobid vajavad oma eluks orgaanilist ainet, õhuhapnikku ja niiskust. Kõik need tegurid on samaaegselt vajalikud, et kindlustada mikroobide kasvu ning arengut, mille tulemusena vabaneb taimedele kasutatav lämmastik. Taimede kasvuks on samuti vajalik õhu ja niiskuse olemasolu mullas, kuid erinevalt mikroobidest vajavad taimed toitumiseks mineraalaineid. Seega on turvasmulla viljakuse eelduseks vee ja õhu vahekorra reguleerimine temas vastavalt mikrobioloogiliste protsesside ning taimekasvu nõuetele. Turvasmulla viljakus tõuseb ainult 
sel juhul, kui ta on muutunud mikrobioloogiliselt aktiivseks. Aktiivse mikrobioloogilise protsessiga turvasmuld vastab nõudeile, mis on püstitatud kultuurmullale, s. t. sisaldab samaaegselt vett ning toitaineid.

Kasulike mikrobioloogiliste protsesside elustamiseks uudissool on vajalik künnikihi korduv läbiōhutamine tema pööramise teel ja eelviljade kas vatamine enne püsiva kultuuri alla viimist. Muidugi avaldab siin head mōju ka mikroobiderikas orgaaniline väetis.

Huvitava näite turvasmulla aktiivseks muutumisest eelvilja ja aereerimise mõjul võiks tuua ENSV TA Maaparanduse ja Sookultuuri Instituudi taimede niiskusetarbe selgitamise katselt. Katse I ja II väljakul oli enne heinakultuure kahel aastal eelviljaks segavili, III väljakul ( 3 ha suurune ala) aga esimesel aastal segavili ja teisel aastal kartul. Kartul pandi eelviljaks 1950. aastal seepärast, et ei saadud pinda heinaseemne külviks küllalt tasaseks ega peeneks, sest pind oli hajusalt kaetud sphagnum-sambla patjadega. 1951. aastal külvati koos I ja II väljakuga ka III väljakule heinakultuurid. 1951. ja 1952. aastal ilmnes heinakasvus III väljakul tunduvaid paremusi, olgugi et turba omadused olid siin enne eelvilja I ja II väljakuga võrreldes halvemad ( $\mathrm{pH} 3,8-4)$. Oeldut võib illustreerida karjakoplite 1952. aasta toodangu vördlusega:

\begin{tabular}{c|c|c|c}
\hline & Koppel 1 & Koppel 2 & Koppel 3 \\
\hline Eelviljaks kartul & & & \\
(III văljak) & 2450 sü & 2448 sü & 2482 sü \\
$\quad \begin{array}{c}\text { segavili } \\
\text { (II văljak) }\end{array}$ & 1775, & 2008, & 2066. \\
$\quad \begin{array}{c}\text { segavili } \\
\text { (I văljak) }\end{array}$ & 1819, & 1637, & 1713.
\end{tabular}

Suurem karjamaatoodang suhteliselt viletsamal turbal tuleb panna 1950. aastal eelviljana kasvatatud kartuli ja selle vaheltharimise arvele.

Mikrobioloogiliste protsesside tagajärjel vabaneb mullas $\mathrm{CO}_{2}$. Mida intensiivsem on bioloogiline tegevus, seda suuremal hulgal vabaneb $\mathrm{CO}_{2}$. Kuidas mõjustab põhjavee sügavus ja künnikihi aeratsioon $\mathrm{CO}_{2}$ ja $\mathrm{O}_{2}$ suhet, mis peaks kaudselt iseloomustama mikrobioloogilisi protsesse mullas, seda mõõdeti vastavatel kohtadel nn. Ors'i hingamisaparaadiga.

Hingamisaparaadiga seotakse turvasmullast vabanev $\mathrm{CO}_{2}$ ja $\mathrm{O}_{2}$; nende suhet nimetatakse mulla hingamiskoefitsiendiks. $10-20 \mathrm{~cm}$ sügavuses turvasmullakihis saadi järgmised tulemused:

\begin{tabular}{c|c|c}
\hline Põhjavee seis cm & Aeratsioon $\%$ & $\begin{array}{c}\text { Hingamiskoefitsient } \\
\text { juulis 1952. a. }\end{array}$ \\
\hline 100 & $40-50$ & $1,55-1,71$ \\
$70-80$ & $25-35$ & $1,25-1,42$ \\
$30-40$ & $10-15$ & $1,16-1,25$
\end{tabular}

Drenaažiga kuivendatud pinnal, kus künnikihi vee- ja õhurežiim oli veel agrotehniliste võtetega reguleerimata, kõikus hingamiskoefitsient $0,6-0,8$ piires. 
Taimede areng ning keemiline koostis erinevate kuivendusnormide juures

Niiskemal alal, kus maapinna keskmine temperatuur $3 \mathrm{~cm}$ sügavusel oli kuivema alaga võrreldes umbes $2-3^{\circ} \mathrm{C}$ kõrgem, algas kevadine taimekasv 4-5 päeva varem, kuid umbes nädala pärast oli taimekasv kuivemal alal ületanud niiskema ala taimekasvu. Ưldreeglina võib taimede arengu ja kasvu kohta erinevate kuivenduste juures öelda: põhjavee tõusuga kiireneb heintaimede ja põllukultuuride areng ning pidurdub kasv. Huvitav on veel märkida, et taimejuurte sügavus on kooskõlas kuivendusnormiga. Mida suurem on kuivendusnorm, seda sügavamale ulatuvad taimejuured. Nii oli kõrreliste heintaimede juuri 100 -sentimeetrise kuivenduse juures leida veel $80 \mathrm{~cm}$ sügavusel.

Kuivendusnormil on väga suur mõju taimede keemilisele koostisele. Mida parem on kuivendus, seda parem on ka taimede kvaliteet. See selgub ilmekalt tabelist 9 .

Tabel 9

Põhjavee sügavuse mõju heintaimede keemilisele koostisele

\begin{tabular}{|c|c|c|c|c|c|}
\hline \multirow[b]{2}{*}{ Kultuur } & \multicolumn{2}{|c|}{ Keskmine } & \multirow{2}{*}{$\begin{array}{l}\text { Kuivheina } \\
\text { saak ts/ha }\end{array}$} & \multirow{2}{*}{$\begin{array}{l}\text { Lămmas- } \\
\text { tiku \% } \\
\text { kuivaines }\end{array}$} & \multirow{2}{*}{$\begin{array}{c}\text { Lubja } \\
(\mathrm{CaO}) \% \\
\text { kuivaines }\end{array}$} \\
\hline & $\begin{array}{l}\text { Põhjavee } \\
\text { seis cm }\end{array}$ & $\begin{array}{l}\text { Aerat- } \\
\text { sioon \% }\end{array}$ & & & \\
\hline $\begin{array}{l}\text { Aasnurmikas } \\
\text { Kerahein } \\
\text { Timut } \\
\text { n }\end{array}$ & $\begin{array}{r}102 \\
45 \\
102 \\
45 \\
102 \\
45\end{array}$ & $\begin{array}{l}48,0 \\
15,7 \\
48,0 \\
15,7 \\
48,0 \\
15,7\end{array}$ & $\begin{array}{l}37,4 \\
16,2 \\
49,1 \\
22,1 \\
58,4 \\
28,9\end{array}$ & $\begin{array}{l}2,07 \\
1,75 \\
2,19 \\
1,32 \\
2,04 \\
1,09\end{array}$ & $\begin{array}{l}0,82 \\
0,77 \\
0,78 \\
0,25 \\
0,66 \\
0,45\end{array}$ \\
\hline
\end{tabular}

Tartu Riikliku Ulikooli taimefüsioloogia kateedri (üliōpilase A. Salu) poolt uuriti askorbiinhappe (vitamiin C) sisaldust kartuli lehtedes õitsemise eel. Kuivendusnormi $60-70 \mathrm{~cm}$ juures sisaldus $100 \mathrm{~g}$ toorlehtedes askorbiinhapet $74 \mathrm{mg}$, kuivendusnormi $80-90 \mathrm{~cm}$ juures $86 \mathrm{mg}$ ja kuivendusnormi $100-110 \mathrm{~cm}$ juures $94 \mathrm{mg}$. Seega näeme, et taime füsioloogilised protsessid intensiivistuvad korraliku kuivenduse ja künnikihi hea õhustuvuse juures.

\section{Kokkuvõte}

Peamiselt 1950., 1951. ja 1952. aasta katsematerjalide põhjal selgus, et sügavad vähemkõdunenud madalsood vajavad kultuuristamisel intensiivset kuivendust. Kuivendusnorm olgu peale soo kuivendusejärgset vajumist vähemalt $70 \mathrm{~cm}$.

Põhjavesi mõjustab künnikihi füüsikalisi tegureid kuni $70-90$ sentimeetrini maapinnast. Põhjavee edasisel alanemisel kultuurse mulla künnikihi füüsikalised tegurid põhjaveest enam ei olene.

Põllumajanduslikele taimedele sobivaks künnikihi aeratsiooniks on mahuliselt $35-50 \%$ ning niiskusetarbeks $50-65 \%$ mulla täielikust veemahutavusest. Toorestel tihedatel kuivendatud uudissoodel tuleb künnikihi vee- ja õhurežiim reguleerida taimekasvatusele sobivaks agrotehniliste võtetega.

Sügavate vähemkõdunenud madalsoode intensiivsel kuivendamisel ei esine nn. ,liigkuivendust”. Kultuurtaimedele jääb $40 \mathrm{~cm}$ tüsedusega künnikihti kevadist kättesaadavat vett $180-200 \mathrm{~mm}$. Sellele veetagavarale lisan- 
dub suviseid sademeid keskmiselt üle $320 \mathrm{~mm}$. Kultuurheina- ja karjamaataimestik vajab normaalseks kasvuks $380-440 \mathrm{~mm}$ vett, seega ei kasutatagi taimede poolt kõike kasulikku niiskust.

Toorestel kuivendatud uudissoopinnastel tuleb künnikihi korduva õhustamise (kündmise) ning eelviljade abil intensiivistada kasulikku mikrobioloogilist tegevust. Selle tagajärjel muutub künnikiht bioloogiliselt aktiivseks ning omandab kultuurmulla tunnused.

Intensiivse kuivenduse (kuivendusnorm üle $70 \mathrm{~cm}$ ) juures muutub kultuurtaimede kvaliteet tunduvalt paremaks. Eriti tõuseb nende lämmastikusisaldus.

\title{
ВЛИЯНИЕ ГЛУБИНЫ ГРУНТОВЫХ ВОД НА ПЛОДОРОДИЕ ТОРФЯНЫХ ПОЧВ
}

\author{
и. А. ЭИЗЕН
}

Резюме

На освоенных торфяно-болотных почвах уровень грунтовых вод оказывает сильное влияние на величину и качество урожая сельскохозяйственных культур. Однако применительно к различным типам торфяно-болотных почв этот вопрос еще слабо изучен. В связи с этим в Институте мелиорации и освоения осушенных земель Академии наук ЭССР (в Тоома) изучалось в полевом опыте влияние уровня стояния грунтовых вод: а) на динамику аэрации и влажности в пахотном горизонте; б) на величину и качество урожая сельскохозяйственных культур.

Опыты проводились на слаборазложившемся (степень разложения $20-25 \%$ ) тростниково-осоковом торфе. На опытном участке, имевшем площадь 12 га, при помощи шлюзов был создан различный уровень грунтовых вод (от 35 см с постепенным падением до $120 \mathrm{~cm}$ ). На опытном участке в течение трех лет высевались культуры: озимая рожь, ячмень, конопля, картофель; турнепс, сахарная свекла, многолетние травы на сено и на выпас. Наиболее высокий и устойчивый урожай полевых, луговых и пастбищных культур был получен на делянках с уровнем стояния грунтовых вод от $70 \mathrm{~cm}$ до $120 \mathrm{~cm}$, при этом начиная от $70-80 \mathrm{~cm}$ до $120 \mathrm{~cm}$ величина урожая указанных культур оставалась почти одинаковой. Напротив, на делянках с уровнем грунтовых вод от 70 см и до 40 см урожай всех культур заметно снижался с повышением уровня грунтовых вод. Так, озимая рожь в течение двух лет давала наиболее высокие урожаи $(21,5$ и 24,0 ц зерна с 1 га) при максимальной норме осушения $(90-120$ см), а при уровне грунтовых вод $40-50$ см урожай зерна ржи составлял только 8-10 ц с 1 га. Урожай сена многолетних трав с 1 га в 1951 году составлял: при норме осушения $100-120 \mathrm{~cm}-45,5$ ц; при норме осушения $70-80$ см - 36,0 ц и при норме осушения 35-40 см - всего лишь 18,4 ц.

Исследования показывают, что наиболее важным физическим фактором, от которого в большей мере зависит плодородие торфяно-болотных почв, является аэрация.

Регулирование водно-воздушного режима торфяной почвы агротехническими приемами заключается преимущественно в регулировании соотношения между капиллярной и некапиллярной пористостью. В некапиллярных порах почвы находится обычно воздух, а в капиллярных по- 
pax - запас почвенной воды. Физические факторы пахотного слоя исследовались на глубнне $10-20$ см и $30-40$ см от поверхности. Почвенные пробы брались с участков под посевами полевых, луговых и пастбишных культур, ежедекадно, в течение всего вегетационного периода.

Қак показывают анализы физических свойств почвы, грунтовые воды влияют на аэрацию пахотного слоя и между ними существует связь только до известной глубины стояния грунтовых вод; грунтовые воды теряют связь с почвенной аэрацией при норме осушения $70-90$ см. При дальнейшем понижении уровня грунтовых вод аэрация и запас почвенной воды теряют зависимость от уровня грунтовых вод.

На опытных делянках с интенсивным осушением в пахотном слое в 40 см было весной в среднем 240 мм воды. При этом аэрация пахотного слоя достигала $30-35 \%$. Такой запас влаги и величина аэрации имеют место там, где нет связи между уровнем грунтовых вод и физическими свойствами пахотного слоя. При более слабом осушении, когда грунтовые воды поступают в пахотный слой по капиллярам, в нем содержится значительно больше воды, а аэрация соответственно уменьшается.

Соответствующими опытами было выяснено, какое количество воды требуется для растений на торфяной почве до момента их увядания. Установлено, что увядание и гибель растений начинается в среднем при 50 $55 \%$ влажности (по весу от сырого торфа). В этом случае в пахотном слое в 40 см остается мертвый запас воды 60 мм. В весенний период запас доступной растениям влаги в почве составляет $240-60=180$ мм.

Летние осадки непрерывно пополняют запас воды в почве. По данным Института мелиорации и освоения осушенных земель, за несколько лет в течение вегетационного периода выпадало в среднем в год 328 мм осадков. Испарение за вегетационный период с окультуренной площади болота (вместе с культурой многолетних трав) в зависимости от года и нормы осушения колеблется в пределах $384-477$ мм. Чем меньше норма осушения, тем больше испарение.

Для успешного произрастания растений на осушенных торфяно-болотных почвах при норме осушения около 100 см запас воды в течение вегетационного периода должен быть следующим: запас полезной влаги в пахотном слое в 40 см - 180 мм; среднее количество осадков - 328 мм; всего доступной (полезной) растениям влаги - 508 мм, которой вполне достаточно для получения высоких урожаев сельскохозяйственных культур. (Из приведенного баланса воды пахотного слоя исключена та часть воды, которая в периоды засухи проникает в пахотный слой в качестве капиллярной воды.)

Таким образом, на участке низинного болота в условиях Тоома переосушения не наблюдалось.

Для усиления микробиологических процессов на̀ новоосвоенном целинном болоте необходимо повторное проветривание пахотного слоя путем перепашки его и посева предварительной культуры до высева многолетних луговых трав. Лучшей предварительной культурой на новоосвоенных болотах является картофель.

Увеличение нормы осушения оказывает значительное влияние на химический состав растений (увеличивается содержание общего азота, кальцня и витаминов, особенно аскорбиновой кислоты - витамина С).

Ннститут мелиорации и освоения осушенных земель Академии наук Эстонской ССР 